\title{
MENGAPA KELOMPOK “TIDAK SETUJU” DIPERLAKUKAN TIDAK SETARA DALAM PILKADA CALON TUNGGAL TAHUN 2015?
}

\author{
Why Did the "Disagree" Group in Single Candidate Local Election 2015 Treated Unequally?
}

\author{
Ikhsan Darmawan \\ Departemen Ilmu Politik, Fakultas Ilmu Sosial dan Ilmu Politik, \\ Universitas Indonesia \\ Alamat e-mail: ikhsan_darmawan@yahoo.com \\ Naskah Diterima: 21 Februari 2017 \\ Naskah Direvisi: 21 April 2017 \\ Naskah Disetujui: 29 Mei 2017
}

\begin{abstract}
Single candidate local election 2015 was happened in three areas: Tasikmalaya Municipality, Blitar Municipality, and Timor Tengah Utara Municipality. In practice, not all people agree with Single Candidate Local Election 2015. In every area where it's local election contains of single candidate, there was group of "disagree" which do not agree with Constitutional Court Decision and then they sounded their rights and legitimacy for choice of "disagree". Nevertheless, in fact, they got different responses with the candidate or "agree" group. This article tries to answer the question: Why did the "disagree" groups not treated equally in three single candidate local elections in 2015? Theoretical framework used in this research is the consequences of electoral laws and relation between democracy and election. This research uses the qualitative approach. Data was collected by using depth interview method in all three areas combined with secondary data from internet. The research result is that the cause of the "disagree" group did not treated equally in single candidate local election is the absence of regulation that can accommodate the problems arise related with single candidate election. As response to that, all three groups of "not agree" in three areas protested the local election bodies. The conclusion of this research is that the phenomenon of not giving space to the "disagree" groups in single candidate local election caused by the regulation that not place "disagree" group as the same and equal stakeholders with candidate in local election.
\end{abstract}

Keywords: single candidate; local election; "disagree" group, discrimination, equality

\begin{abstract}
Abstrak
Pilkada calon tunggal tahun 2015 terjadi di tiga daerah, yaitu Kabupaten Tasikmalaya, Kabupaten Blitar, dan Kabupaten Timor Tengah Utara. Dalam praktiknya, tidak semua pihak setuju dengan Pilkada calon tunggal tahun 2015. Di tiap daerah yang Pilkadanya terdiri dari calon tunggal, terdapat kelompok "tidak setuju" yang awalnya tidak setuju dengan putusan MK tentang Pilkada calon tunggal lalu mereka menyuarakan kesetaraan hak dan pengakuan untuk pilihan "tidak setuju". Akan tetapi, pada kenyataannya, mereka mendapatkan perlakuan yang tidak setara dengan calon atau kelompok "setuju". Artikel ini berusaha untuk menjawab pertanyaan: Mengapa kelompok "tidak setuju" diperlakukan tidak setara dalam Pilkada calon tunggal di tahun 2015? Kerangka pemikiran yang digunakan dalam penelitian ini adalah konsekuensi dari aturan pemilu dan hubungan antara demokrasi dan pemilu. Penelitian ini menggunakan pendekatan kualitatif. Pengumpulan data dilakukan dengan cara wawancara mendalam di ketiga daerah disertai pengumpulan data-data sekunder dari sumber internet. Hasil dari penelitian ini adalah bahwa penyebab tidak diakomodirnya kelompok "tidak setuju" di ketiga daerah yang melaksanakan Pilkada calon tunggal di tahun 2015 adalah ketiadaan aturan yang dapat mengakomodir persoalan-persoalan yang muncul terkait Pilkada calon tunggal. Sebagai reaksi dari hal itu, ketiga kelompok "tidak setuju" di ketiga daerah melakukan usaha perlawanan dan protes kepada penyelenggara Pilkada. Simpulan penelitian ini yaitu fenomena tidak diberi ruang yang sama untuk kelompok "tidak setuju" dalam Pilkada calon tunggal disebabkan oleh aturan yang tidak menempatkan kelompok "tidak setuju" sebagai pihak yang sama dan setara dengan calon kepala daerah.
\end{abstract}

Kata kunci: calon tunggal, Pilkada, kelompok "tidak setuju”, diskriminasi, kesetaraan 


\section{Latar Belakang}

Pilkada Serentak tahun 2015 telah dilaksanakan pada 9 Desember 2015 lalu di 264 daerah. Rinciannya yaitu: 8 provinsi, 242 kabupaten, dan 34 kota. Sebenarnya, pelaksanaan Pilkada Serentak di tahun 2015 direncanakan akan digelar di 269 daerah. Namun, pada saat terakhir, Pilkada di lima daerah tidak dilaksanakan pada 9 Desember 2015 dikarenakan sejumlah sebab. Lima daerah itu adalah: Provinsi Kalimantan Tengah, Kabupaten Fakfak di Papua, Kabupaten Simalungun dan Kota Pematangsiantar di Sumatra Utara dan Kota Manado di Sulawesi Utara.

Darijumlah total daerah yang melaksanakan Pilkada di atas, ada 3 (tiga) daerah yang diikuti oleh hanya satu pasang calon dan lazim disebut dengan istilah Pilkada calon tunggal. Ketiga daerah itu adalah Pilkada Kabupaten Tasikmalaya, Kabupaten Blitar, Kabupaten Timor Tengah Utara.

Pilkada calon tunggal merupakan pelaksanaan dari putusan MK No. 100/PUUXIII/2015. Putusan MK itu merupakan jawaban darigugatan EffendiGhazali. Dalam gugatannya, Effendi Ghazali menggugat pasal-pasal di UU No. 8 Tahun 2015 yang mensyaratkan sebuah Pilkada wajib dilaksanakan setidaknya dua pasangan calon. Dampak dari pasal-pasal di UU No. 8 Tahun 2015 adalah ditundanya pelaksanaan Pilkada di daerah yang hanya terdiri dari satu pasang calon. Penundaan Pilkada menyebabkan terjadinya kekosongan pejabat definitif di daerah tersebut karena hanya dipimpin oleh pejabat sementara dan juga dalam kurun waktu yang tidak sebentar.

Beberapa waktu sebelum keluarnya putusan MK No. 100/PUU-XIII/2015 pada 29 September 2015, di daerah-daerah yang hanya terdapat satu calon dalam Pilkada-nya telah dilaksanakan penundaan Pilkada menjadi di Pilkada Serentak selanjutnya (2017-penulis). Akan tetapi, dengan keluarnya putusan MK itu, KPU RI kemudian memutuskan untuk membuka kembali tahapan Pilkada di ketiga daerah yang terdiri dari calon tunggal yang sebelumnya sempat diberhentikan.
Akan tetapi, bukan berarti pilihan kebijakan dari KPU RI itu selalu didukung tanpa kecuali. Sebaliknya, ada orang-orang yang tidak setuju dan menolak pelaksanaan Pilkada calon tunggal. Di ketiga daerah, Kabupaten Tasikmalaya, Kabupaten Blitar, dan Kabupaten Timor Tengah Utara, terdapat kelompok-kelompok masyarakat yang menolak dan tidak setuju dengan digelarnya Pilkada Calon Tunggal.

Salah satu alasan penolakan mereka yaitu pelaksanaan putusan MK tidak berlaku untuk Pilkada Serentak 2015 melainkan Pilkada Serentak 2017 karena putusan itu tidak dapat berlaku surut. Alasan lainnya adalah karena KPU Kabupaten di ketiga daerah telah menutup tahapan Pilkada dan status pasangan calon belum sempat diverifikasi menjadi calon, sehingga sebenarnya Pilkada di ketiga daerah itu belum terdapat calon kepala daerah sama sekali. Sementara itu, di dalam isi putusan MK terkesankan bahwa di ketiga daerah itu sudah terdapat calon kepala daerah.

Pilkada yang hanya terdiri dari satu calon ini menimbulkan perdebatan apakah masuk dalam kategori demokratis atau tidak. Seperti diungkapkan oleh McDonald dan Samples: "Democratic elections are about choice between competing candidates and the issues they intend to follow if elected." 1 (Pemilu-pemilu yang demokratis adalah mengenai pilihan di antara kandidat-kandidat yang berkompetisi dan isu yang mereka akan laksanakan jika terpilih). Dalam pertanyaannya, McDonald dan Samples menggunakan istilah kandidat-kandidat yang artinya "jamak" atau lebih dari satu. Dengan demikian, pemilu yang demokratis identik dengan terdiri dari minimal dua kandidat.

Kelompok-kelompok yang tidak setuju dengan Pilkada calon tunggal di ketiga daerah itu kemudian mentransformasikan diri mereka menjadi kelompok "tidak setuju". Karena Pilkada di daerah mereka tetap dilaksanakan dengan satu pasang calon, kelompok "tidak

Michael P. McDonald dan John Samples (eds.), The Marketplace of Democracy: Normative and Empirical Issues (Washington DC: Brookings Institution Press, 2007), 2. 
setuju" tetap melanjutkan eksistensi mereka. Mereka dapat dikelompokkan sebagai kelompok yang memilih "tidak setuju" dan memperjuangkan agar pilihan "tidak setuju" dapat mengalahkan pilihan "setuju". Artikel ini ingin memfokuskan pada kelompok "tidak setuju" seperti dimaksud di atas.

\section{Permasalahan}

Permasalahan yang menarik dari Pilkada calon tunggal tahun 2015 adalah ternyata di ketiga wilayah Pilkada calon tunggal tidak seperti Pilkada lain pada umumnya. Calon pemilih bukan memilih orang atau pasangan calon melainkan pilihan "setuju" atau "tidak setuju". Di kertas surat suara terdapat foto pasangan calon yang membawahi kotak bertuliskan "setuju" dan "tidak setuju" (lihat Gambar 1).
Ada beberapa indikasi terkait perlakukan tidak setara terhadap kelompok "tidak setuju" itu. Pertama, dari model surat suara seperti di atas bahwa Pilkada calon tunggal hanya menganggap calon saja (atau kelompok "setuju") karena posisi dari foto pasangan calon berada di atas dari kotak setuju dan tidak setuju. Jika ingin adil dalam bersikap, sebaiknya model surat suara yang terdapat foto pasangan calon sebaiknya diubah sehingga menjadi hanya kotak bertuliskan "setuju" atau "tidak setuju" saja. Foto pasangan calon bisa saja hanya ada di TPS dan terpisah dari surat suara.

Kedua, penyelenggara Pilkada hanya melaksanakan sosialisasi untuk pilihan "setuju" saja kepada masyarakat setempat karena anggapan mereka adalah bahwa kelompok "tidak setuju" bukanlah calon. Sebagai contoh di Kabupaten Tasikmalaya, KPU Kabupaten Tasikmalaya hanya

\section{Gambar 1}

Contoh Surat Suara di Pilkada Kabupaten Tasikmalaya

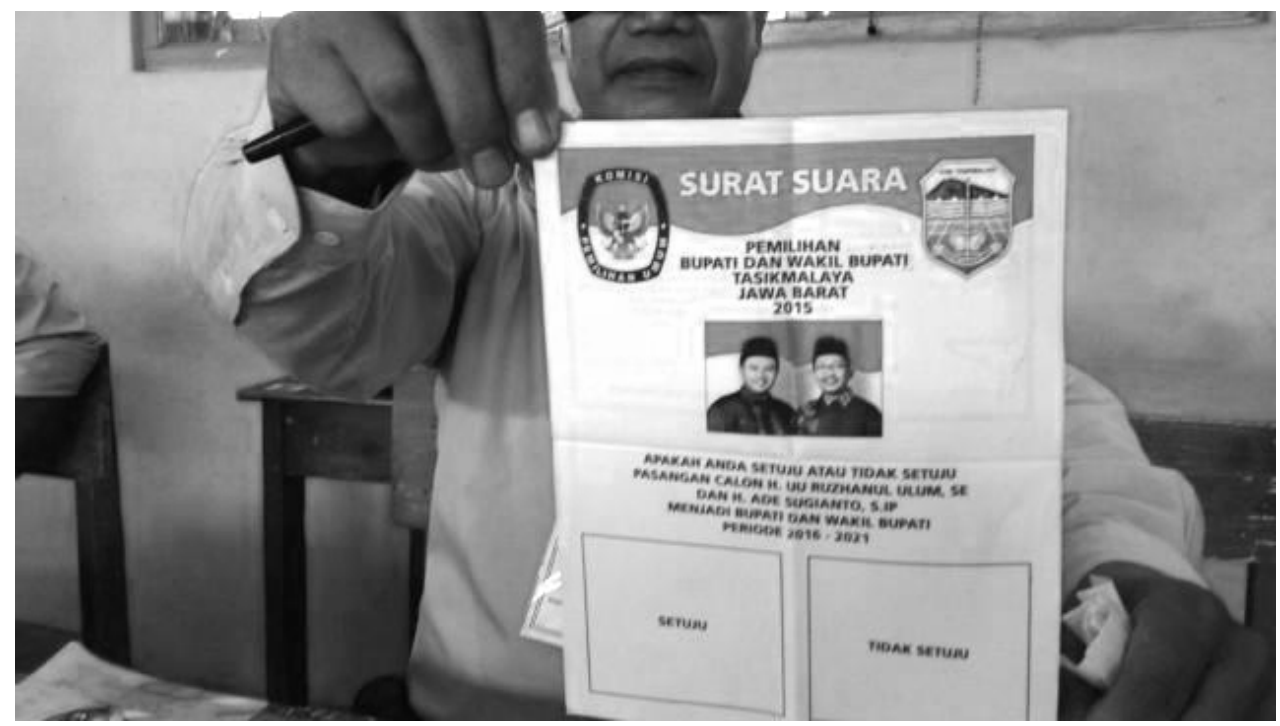

Sumber: bbc.com

Ada kesan kuat bahwa kelompok "tidak setuju" diperlakukan tidak setara dalam Pilkada calon tunggal tahun 2015. Apa maksud dari kelompok "tidak setuju" yang diperlakukan tidak setara? Artinya, kelompok yang sebelumnya menolak Pilkada calon tunggal dan ingin mengkampanyekan pilihan "tidak setuju" tidak diakui dan tidak diberi ruang, perlakuan, dan kesempatan yang sama dengan kelompok "setuju" saat Pilkada calon tunggal dilaksanakan. membuat dan memasang alat peraga kampanye untuk pasangan calon saja (lihat Gambar 2).

Dalam kasus di dua daerah, yaitu Kabupaten Tasikmalaya dan Kabupaten Timor Tengah Utara, sebelum Pilkada 9 Desember 2015 lalu terjadi demonstrasi oleh masyarakat di kedua daerah tersebut yang menyuarakan kesetaraan hak dan pengakuan untuk pilihan "tidak setuju". Tidak hanya diakui, "pilihan tidak setuju" seharusnya juga dibiayai oleh negara. Apa yang disuarakan oleh kelompok masyarakat itu 
adalah sebuah hal yang logis dan wajar karena Pilkada calon tunggal sesungguhnya adalah manifestasi dari model referendum. ${ }^{2}$

Di samping itu, hak untuk mendapatkan perlakuan yang sama seharusnya bersifat setara (non-diskriminatif) dalam konteks model pemilihan referendum tersebut. Faktanya, di ketiga daerah Pilkada calon tunggal baik alat peraga kampanye sampai dengan model surat suara terlihat bahwa pilihan "tidak setuju" tidak diberikan perlakuan yang tidak diskriminatif.
Pilkada calon tunggal yang diselenggarakan di tiga daerah pada tahun 2015; dan

- Menjelaskan mengapa kelompok "tidak setuju" diperlakukan tidak setara dalam Pilkada calon tunggal tahun 2015.

\section{Kerangka Pemikiran}

Sebagai pisau analisis, artikel ini menggunakan kerangka pemikiran pengaruh aturan pemilu alias konsekuensi politik dari electoral laws atau peraturan tentang pemilu.

Gambar 2

Foto Spanduk Kampanye oleh KPU di Pilkada Kabupaten Tasikmalaya

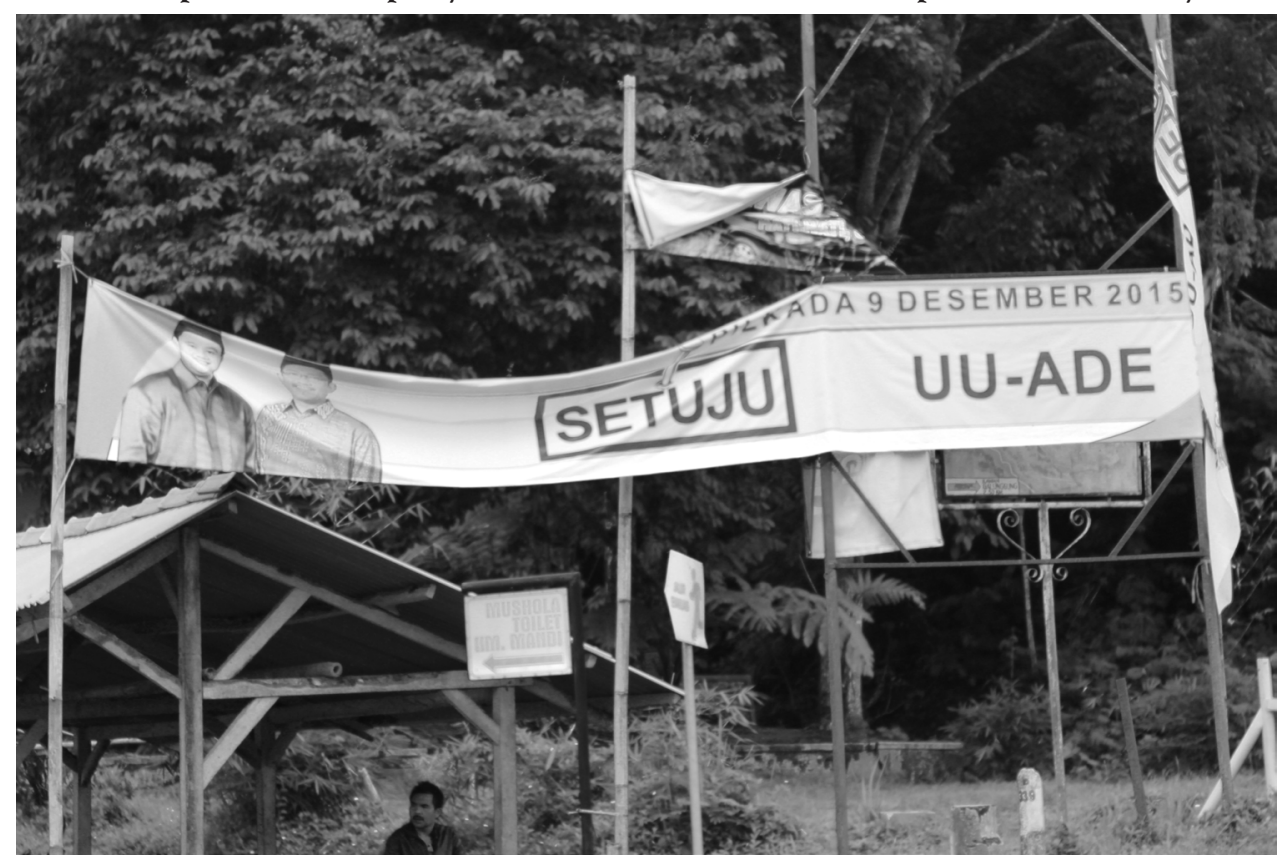

Sumber: Koleksi penulis.

Berangkat dari latar belakang permasalahan di atas, artikel ini ingin menjawab pertanyaan: Mengapa kelompok "tidak setuju" diperlakukan tidak setara dalam Pilkada calon tunggal di tahun 2015? Artikel ini berpendapat bahwa perlakuan tidak setara terhadap kelompok "tidak setuju" disebabkan oleh ketiadaan aturan yang dapat mengakomodir persoalan-persoalan yang muncul terkait Pilkada calon tunggal.

\section{Tujuan Penulisan}

Artikel ini ditulis dengan tujuan:

- Memberikan gambaran mengenai kelompok-kelompok "tidak setuju" dalam

Ikhsan Darmawan, "Mengantisipasi Pilkada Calon Tunggal”, Kompas, 14 September 2016, 6.
Karya terkait pengaruh aturan pemilu yang paling notable adalah dari Arend Lijphart. Dalam artikelnya itu, Lijphart mengemukakan bahwa aturan pemilu (khususnya sistem pemilu beserta variabel-variabelnya seperti electoral formula, district magnitude, dan ballot structure) memiliki kaitan erat dengan hasil pemilu (electoral outcome). ${ }^{3}$ Karya Lijphart itu

Arend Lijphart. "The Political Consequences of Electoral Laws, 1945-85," The American Political Science Review 84, no. 2 (Juni 1990): 481-496. Studi lain yang sejenis lihat juga Bernard Grofman dan Arend Lijphart (Eds.), Electoral Laws and Their Political Consequences, (New York: Agathon Press Inc, 1986), Kenneth Benoit, "Duverger's Law and the Study of Electoral System", French Politics 4, (2006): 69-83, Kenneth Benoit, "Electoral Laws as Political Consequences: Explaining the Origins and Change of Electoral Institutions", Annu. Rev. Polit. Sci. 10, 
merupakan respons terhadap karya sebelumnya dari Douglas Rae yang mengambil tema yang sama. ${ }^{4}$ Meskipun karya Rae disebut-sebut sebagai karya yang populer, akan tetapi terdapat juga kritik terhadap karya itu, khususnya pada aspek-aspek konseptual, metodologi, dan empiris.

Karya sejenis dengan Lijphart dan Rae dapat dilihat dari karya Blais dkk yang melihat diputuskannya dalam peraturan tentang pemilu yang membatasi usia minimal pemilih (yaitu 18 tahun) dan hak untuk memilih dari orang yang berkebutuhan mental khusus perlu dibatasi. ${ }^{5}$ Kesamaan karya Blais dkk dengan paper ini adalah keduanya sama-sama melihat faktor yang mempengaruhi aturan tentang pemilu.

Selain kerangka pemikiran di atas, artikel ini juga menggunakan kerangka pemikiran hubungan antara demokrasi dan pemilu. Pemilu yang demokratis ditandai oleh banyak indikator. Salah satunya adalah pemilu tersebut harus bebas dari praktik diskriminatif. ${ }^{6}$ Selain itu, dalam mendukung pemilu demokratis harus juga terdapat political equality atau kesetaraan politik di dalam pemilu. Apakah kesetaraan politik dalam pemilu itu? Robert Dahl dan Charles Lindblom mendefinisikan kesetaraan politik dalam pemilu sebagai "pilihan setiap

(2007): 363-90, Shaun Bowler, Elisabeth Carter, dan David M. Farrell, Studying Electoral Institutions and Their Consequences: Electoral Systems and Electoral Laws,

CSD Working Papers, 2001. Diakses 21 Februari 2017, http:// escholarship.org/uc/item/7dc5b9dg, Giovanni Capoccia, "The Political Consequences of Electoral Laws: The German System at Fifty", West European Politics 25, no. 3, (2002): 171-202, William R. Clark dan Matt Golder, "Rehabilitating Duverger's Theory: Testing the Mechanical and Strategic Modifying Effects of Electoral Laws", Comparative Political Studies 39, no. 6,(2006): 679-708.

4 Douglas Rae, The Political Consequences of Electoral Laws. (Yale: Yale University Press, 1967). Analisis lebih lanjut studi Lijphart dan Rae dalam kasus Amerika Latin dan Karibia lihat Mark P. Jones, "The Political Consequences of Electoral Laws in Latin America and the Caribbean", Electoral Studies 12, no. 1 (1993), 59-75.

Andre Blais, Louis Massicotte, dan Antoine Yoshinaka, "Deciding Who Has The Right to Vote: A Comparative Analysis of Election Laws", Electoral Studies 20, no. 1 (March 2001): 41-62.

6 Stephen J. Wayne. Is This Any Way To Run a Democratic Election? (Los Angeles: Sage Publication, 2014), 5. orang memiliki ukuran yang sama". ${ }^{7}$ Tak hanya suara, kesetaraan politik dalam pemilu demokratis juga wajib ada dalam hal lain seperti kesetaraan politik antar kandidat.

Penelitian terdahulu tentang Pilkada calon tunggal masih sangat terbatas mengingat fenomena Pilkada calon tunggal merupakan fenomena yang masih relatif baru di Indonesia. Penelitian terdahulu yang pernah ada dilakukan oleh Wafia Silvi Dhesinta. Fokus dari riset tersebut adalah pada kelemahan dalam pelaksanaan Pilkada calon tunggal Kabupaten Blitar. ${ }^{8}$ Kelemahan itu adalah kurangnya sosialisasi mengenai tata cara pemungutan suara. Selain itu, penelitian tersebut juga menganalisis mengenai tidak demokratisnya Pilkada dengan satu calon tersebut.

Sementara itu, dalam konteks riset tentang pemilihan yang dilakukan dengan hanya satu calon, selama ini identik dengan pemilihan di negara nondemokratik. Sebagai contoh, Pemilihan Presiden Yaman di tahun 2012 di mana calon presiden kala itu hanya Abduradu Mansur Hadi. ${ }^{9}$

Kepustakaan yang menjelaskan pemilihan dengan satu calon identik dengan yang terjadi di China. Dalam karya Cheng Li disebutkan bahwa dalam pemilihan di internal partai (Partai Komunis China atau China Communist Party), terdapat tahap di mana untuk setiap posisi yang ingin diisi hanya terdapat satu calon saja. ${ }^{10}$ Meskipun demikian, belakangan ini terdapat perubahan dalam mekanisme dan prosedur pemilihan di negara China, khususnya Pemilihan Kepala Desa. ${ }^{11}$ Akan tetapi, Kennedy

Robert Dahl dan Charles Lindblom, Politics, Economics, and Welfare, (New York: Harper and Bros, 1953), dalam Jonathan W. Still. "Political Equality and Election Systems", Ethics 91, no. 3 (Apr., 1981): 375-394.

Wafia Silvi Dhesinta, "Calon Tunggal dalam Pemilihan Umum Kepala Daerah dan Konsep Demokrasi: Analisis Terhadap Pemilihan Kepala Daerah Kabupaten Blitar Tahun 2015", Jumal Cita Hukum, Vol. 4 No. 1 (2016): 87-104.

9 Yemen holds presidential election with one candidate http://edition.cnn.com/2012/02/21/world/meast/yemenelections/, (cnn.com).

10 Cheng Li, From Selection to Election? Experiments in the Recruitment of Chinese Political Elities, China Leadership Monitor, No. 26.Cheng Li, 4.

11 Kevin J. O’Brien dan Rongbin Han, "Path to Democracy?: Assesing Village Elections in China", Journal of Contemporary China, 18, no. 60, (2008): 3. 
tidak sependapat dengan O'Brien dan Han karena walaupun lebih kompetitif dibanding sebelumnya, akan tetapi siapa yang menjadi calon atau kandidat ditentukan terlebih dahulu oleh sekelompok orang sehingga menyebabkan pilihan pemilu menjadi lebih terbatas. ${ }^{12}$

Kebaruan ilmiah dari artikel ini adalah bahwa penelitian ini mengangkat tentang kasus Pilkada calon tunggal yang masih relatif baru dan juga dilihat dari perspektif penyelenggaraan pemilu, khususnya pengaturan terkait kelompok "tidak setuju". Kasus Pilkada calon tunggal di Indonesia menunjukkan bahwa pemilu dengan satu calon tidak hanya terjadi di negara yang tidak demokratis, tetapi juga di negara demokratis seperti Indonesia.

\section{Metodologi}

Artikel ini ditulis dari hasil penelitian yang dilakukan dengan menggunakan pendekatan kualitatif. Pendekatan kualitatif dipilih karena penulis ingin lebih menekankan pada kedalaman data.

Metode penentuan kasus yaitu dilakukan dengan metode pengambilan seluruh populasi karena pada tahun 2015 kasus Pilkada calon tunggal terjadi di 3 (tiga) daerah. Penelitian terhadap keseluruhan populasi diharapkan dapat mengarah kepada generalisasi sekaligus menggambarkan keunikan dari masing-masing kasus.

Data sekunder dan primer yang telah dikumpulkan kemudian dikategorisasi. Setelah itu, data tersebut dianalisis dengan dikaitkan dengan kerangka analisis yang relevan sehingga memperkuat jawaban atas pertanyaan penelitian.

Pengumpulan data dilakukan secara bertahap dari mulai November 2015 sampai dengan Agustus 2016 di ketiga kabupaten seperti disebutkan di atas. Pengambilan data pertama dilakukan di Kabupaten Tasikmalaya sebelum, pada hari-H, dan setelah Pilkada dalam kurun waktu November 2015 sampai awal tahun 2016.

\footnotetext{
12 James John Kennedy, "The Face of "Grassroots Democracy" in Rural China: Real Versus Cosmetic Elections", Asian Survey, 42, no. 3 (2002): 456-482.
}

Pengumpulan data kedua dilakukan di Kabupaten Timor Tengah Utara pada bulan Agustus 2016. Terakhir, pengumpulan data dilakukan di Kabupaten Blitar pada bulan yang sama dengan di Timor Tengah Utara.

Untuk teknik pengumpulan data dilakukan dengan tiga cara. Cara pertama adalah pengumpulan data-data sekunder dari beritaberita online tentang Pilkada di ketiga daerah. Cara kedua, adalah dengan melakukan observasi di Kabupaten Tasikmalaya. Karena dilaksanakan secara serentak, maka observasi hanya dapat dilakukan di satu daerah saja. Cara ketiga, adalah dengan melakukan wawancara mendalam kepada para informan-informan terkait riset ini. Latar belakang informan yang diwawancarai antara lain: KPU Kabupaten, Panwas Kabupaten, akademisi di daerah tersebut, pengurus partai politik-partai politik di masing-masing kabupaten, dan kelompok yang termasuk dalam kelompok "tidak setuju" di tiap kabupaten.

\section{Kelompok “Tidak Setuju” di Pilkada Kabupaten Tasikmalaya}

Kelompok "tidak setuju" di Kabupaten Tasikmalaya awalnya berasal dari orang-orang yang mendorong agar Pilkada Kabupaten Tasikmalaya hanya diikutioleh satu pasang calon sehingga menjadi ditunda di Pilkada Serentak 2017. Akan tetapi, dalam perkembangannya kelompok ini tak hanya terdiri dari elit-elite partai politik saja, namun juga melebar sampai pada kelompok masyarakat (mahasiswa).

Elite-elite partai politik dari kelompok ini berasal dari partai politik di luar partai pengusung Bupati Tasikmalaya petahana (Uu Ruzhanul Ulum). Partai-partai politik dimaksud adalah PPP (kubu Djan Faridz) dan Partai Demokrat. ${ }^{13}$

$13 \quad$ Partai politik-partai politik pengusung dan pendukung Uu Ruzhanul Ulum dan Ade Sugiyanto (Bupati dan Wakil Bupati Tasikmalaya petahana) adalah PPP (kubu Romahurmuzy), PDI Perjuangan, Partai Golkar, PAN, dan PKS. Partai Golkar hanya berstatus pendukung karena bermasalah dalam hal dualisme kepengurusan di tingkat pusat kala itu antara Aburizal Bakrie dan Agung Laksono. Wawancara dengan Erry Purwanto, salah seorang pengurus Partai Golkar Kabupaten Tasikmalaya di Gedung DPRD Kabupaten Tasikmalaya pada tanggal 6 Januari 2016. 
Sementara itu, PKB memilih untuk tidak memihak kepada calon atau kubu manapun setelah gagal mencapai kesepakatan dengan $\mathrm{Uu}$ Ruzhanul Ulum. ${ }^{14}$ Sedangkan, untuk kelompok masyarakat berasal dari Forum Komunikasi Masyarakat Kota Tasikmalaya (FKMT) yang diketuai oleh Dani Safari Effendi. ${ }^{15}$ Kelompok ini menamakan dirinya dengan Romantis yang merupakan singkatan dari Rombongan Masyarakat Tidak Setuju.

Sebelum terjadi Pilkada calon tunggal di Kabupaten Tasikmalaya, sebenarnya sudah banyak bakal calon bupati yang bermunculan. Akan tetapi, mendekati masa pendaftaran, para bakal calon itu kemudian tidak jadi mencalonkan. Seperti disampaikan oleh Ikbal Nasihin sebagai berikut:

"Itu awalnya. Kita ada dua calon, dua kekuatan besar, kedua-duanya kader PPP, Pak Ketua DPRD sama bupati. Karena mungkin ini juga apalagi ketika sekarang ini PPP lagi gamang, galau gitu kan karena kepengurusan pusat yang nggak bener gitu, akhirnya kita kan yang di bawah jadi tidak solid di kabupaten kota ketika kepentingan-kepentingan ini saling bertabrakan. Akhimya kejadian seperti ini dimanfaatkan oleh partai lain bagaimana supaya diundur 2017.

Menurut Ikbal, partai politik-partai politik lain di luar PPP terkesan tidak ingin PPP terus menduduki kursi bupati Tasikmalaya. Apalagi, dua bakal calon yang berniat maju sama-sama dari PPP. Berangkat dari situ, partai politik lain berusaha menjegal agar PPP tidak berhasil maju karena Bupati Tasikmalaya Uu Ruzhanul Ulum saat itu berada di kubu PPP yang belum jelas

14 Jauh hari sebelum pendaftaran calon bupati dan wakil bupati Tasikmalaya, Uu Ruzhanul Ulum sudah mendekati PKB Kabupaten Tasikmalaya untuk menjajaki kemungkinan maju bersama di mana wakil bupati akan berasal dari PKB. Hal itu dilakukan Uu karena PPP mengalami masalah dualisme kepengurusan sehingga sangat rentan untuk tidak dapat mengajukan pasangan calon sendiri meskipun PPP memiliki jumlah kursi terbanyak di DPRD Kabupaten Tasikmalaya. Wawancara dengan Usman Kusmana, anggota DPRD Kabupaten Tasikmalaya dari PKB pada tanggal 6 Januari 2016 di Gedung DPRD Kabupaten Tasikmalaya.

15 Dani Safari Effendi adalah mahasiswa aktif S1 Ilmu Hukum Universitas Galunggung, Kabupaten Tasikmalaya. FKMT terdiri dari mahasiswa-mahasiswa Ilmu Hukum Universitas Galunggung, Kabupaten Tasikmalaya. keabsahan kepengurusannya. Hasilnya tercapai kesepakatan bahwa semua elit partai politik sama-sama tidak mencalonkan diri agar Pilkada Kabupaten Tasikmalaya diundur ke tahun 2017. Seperti diungkapkan oleh Ikbal Nasihin:

"Mereka juga tidak mau kayaknya rezim PPP terus berkuasa di Tasik karena siapapun yang menang, kalau Pak Rohimat sama Pak Uu maju, keliatannya teman-teman dari partai lain agak enggan. Gitu. Karena siapapun yang jadi tetap PPP. Karena itulah ya kan Pak Ade Ketua DPC PDIP melobi bagaimana supaya Pilkada 2015 ini digagalkan. Melobi kita-kita, melobi partaipartai kumpul di Restoran Permata Kota Tasik, semua ketua partai kumpul dan sepakat diundur 2017. Dan mendesak supaya Pak Rohimat tidak mencalonkan diri. Biarlah Pak Uu saja yang nyalon. Yang daftar. Pak Rohimat nggak perlu daftar. Akhirnya sepakat semua diundur ke 2017... Biarlah Pak Uu sama Pak Ade. Pak Ade kan ketua DPC, biarlah Pak Ade aja yang daftar sama Pak Uu. Biarlah nanti diputus sama KPU. Begitu juga komunikasi dengan KPU ya udah kita undur saja. calonnya cuma satu. Akhirnya nggak lama ditutup pendaftaran. Hari itu pleno diundur ke 2017 sebelum ada putusan MK. Motivasinya ya itu, ingin kesetaraanlah." 16

Seperti disebutkan sebelumnya, Bupati Tasikmalaya petahana, Uu Ruzhanul Ulum, memang tidak mendapatkan rekomendasi untuk dicalonkan oleh PPP yang mengusungnya di tahun 2010. Apalagi, pada akhir Oktober 2015, Mahkamah Agung (MA) mengeluarkan putusan yang memenangkan kubu Djan Faridz sebagai kasus hukum sengketa kepengurusan PPP yang sah. Putusan MA itu memberikan penegasan bahwa PPP tidak akan mendukung Uu Ruzhanul Ulum sebagai calon Bupati Tasikmalaya meskipun Uu merupakan kader PPP. 17

Kelompok Romantis tidak menyangka bahwa MK akan mengeluarkan Putusan MK

16 Wawancara dengan Ikbal Nasihin, salah satu pengurus PPP (Kubu Djan Faridz) di Kantor PPP (Kubu Djan Faridz) Kabupaten Tasikmalaya, pada tanggal 6 Januari 2016.

17 "Pasca putusan MA, PPP tak akan usung Uu di Pilkada Tasikmalaya", diakses 8 November 2015, pukul 10:23 WIB, http://m.galamedianews.com/daerah/49796/pascaputusan-ma-ppp-tak-usung-uu-di-pilkada-tasikmalaya. html. 
No. 100 yang substansinya tetap meminta Pilkada dilaksanakan meskipun hanya diikuti oleh satu pasang calon saja. Sebagai respons dari keputusan KPU RI tetap melaksanakan Pilkada calon tunggal di Kabupaten Tasikmalaya, kelompok Romantis melakukan beberapa kegiatan. Salah satunya adalah menyatakan penolakan terhadap pelaksanaan Pilkada calon tunggal. Seperti diungkapkan oleh Ikbal Nasihin:

"25 Oktober kalau nggak salah. Ketika simulasi. Ketika simulasi itu kan kumpul dengan semua ketua semua ormas, ketua partai, dengan KPU RI dengan Bawaslu RI bahkan DKPP pun hadir. Ya kita mempermasalahkan itu, kita mempertanyakan ini dasar hukum calon tunggal itu darimana? Undang-undangnya nggak ada. Ini jelas-jelas melanggar HAM melanggar UUD. Yang lebih parah lagi melanggar Pancasila. Karena sistem yang dibangun setelah munculnya PKPU apalagi. Kita tidak punya. Bagi yang tidak setuju, kita kan tidak diberi fasilitas apapun. Kita tidak punya hak legal standing, kita juga tidak punya hak untuk mensosialisasikan tidak setuju dengan APBD yang ada. Kita juga tidak punya hak untuk sakasi, untuk mengontrol kecurangan mereka tidak punya kita." 18
Karena akhirnya Pilkada calon tunggal tetap dilaksanakan, maka kelompok ini tetap beraktivitas dengan menyuarakan dan mengkampanyekan pilihan "tidak setuju" sekaligus mendorong kesamaan perlakuan dengan pilihan "setuju". Meskipun tidak diatur atau diakomodir dalam peraturan, baik Undang-Undang maupun Peraturan KPU, kelompok Romantis ini tetap mengkampanyekan pilihan "tidak setuju" kepada masyarakat Kabupaten Tasikmalaya. Pada tanggal 29 Oktober 2015, kelompok ini melakukan sosialisasi pilihan "tidak setuju" di Pondok Pesantren Al Choeriyah, di Kampung Cibeas, Desa Cintaraja, Kecamatan Singaparna, Tasikmalaya. Salah satu yang melakukan sosialisasi adalah Tatang Farhanul Hakim, mantan Bupati Tasikmalaya, yang merupakan Ketua DPW PPP Jawa Barat versi Djan Faridz. Dalam kesempatan itu, Tatang menyebutkan bahwa alasan mensosialisasikan pilihan "tidak setuju" adalah agar masyarakat diberi ruang dalam memilih calon jika Pilkada Kabupaten Tasikmalaya diundur ke tahun 2017. Sosialisasi itu sendiri juga dihadiri oleh Ketua Majelis Ulama (MUI) Kabupaten Tasikmalaya, Abdul Baasyit. ${ }^{19}$

Gambar 3

Foto Spanduk Kelompok “Tidak Setuju” di Pilkada Kabupaten Tasikmalaya

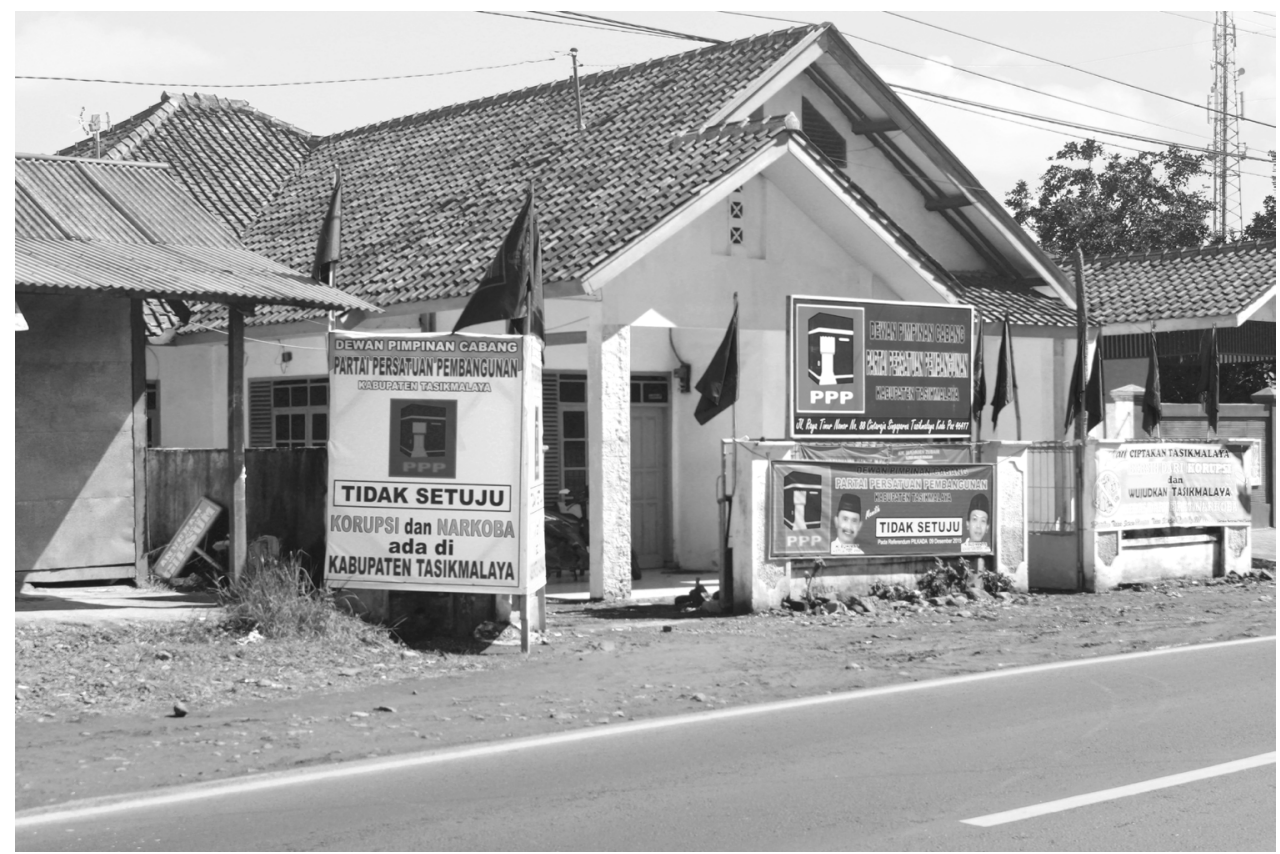

Sumber: Koleksi penulis.

18 Wawancara dengan Ikbal Nasihin, salah satu pengurus PPP (Kubu Djan Faridz) di Kantor PPP (Kubu Djan Faridz) Kabupaten Tasikmalaya, pada tanggal 6 Januari 2016.
19 "Mantan Bupati Kampanyekan Suara Tidak Setuju", diakses 8 November 2015, pukul 10:25 WIB, http://v2.rri.co.id/ post/berita/214082/pilkada_serentak_2015/mantan_bupati_ kampanyekan_suara_tidak_setuju_di_tasikmalaya.html. 
Setelah itu, pada 1 Desember 2015 malam, $\mathrm{H}$. Ruhimat mengadakan rapat di rumahnya. Rapat itu membahas rencana mengadakan Deklarasi Kelompok “Tidak Setuju”. Deklarasi direncanakan akan digelar di depan kantor Bupati Tasikmalaya. ${ }^{20}$

Walaupun tidak diakomodir secara khusus seperti tertulis dalam peraturan, pada praktiknya KPU Kabupaten Tasikmalaya tetap menjalankan kewajiban mereka mensosialisasikan Pilkada dengan calon tunggal. Kebaruan model calon tunggal ini relatif tidak mudah disosialisikan. Dadan Bardan, anggota KPU Kabupaten Tasikmalaya divisi teknis pemilu dan hubungan partisipasi masyarakat, mengatakan KPU Kabupaten Tasikmalaya bekerja lebih keras mensosialisasikan Pilkada calon tungal kepada masyarakat Kabupaten Tasikmalaya. Hal ini dikarenakan masyarakat model surat suara yang memilih pilihan tulisan "setuju" atau "tidak setuju". ${ }^{21}$

\section{Kelompok “Tidak Setuju” di Pilkada Kabupaten Blitar}

Seperti halnya di Kabupaten Tasikmalaya, kelompok "tidak setuju" di Pilkada Kabupaten Blitar terdiri dari elite-elite partai politik yang berseberangan dengan kepala daerah petahana. Hanya saja, bedanya dengan di Kabupaten Tasikmalaya, di Kabupaten Blitar kepala daerah petahana yang dimaksud adalah Wakil Bupati. Hal ini dikarenakan Bupati Blitar petahana sudah menjabat sebanyak dua periode.

Kelompok "tidak setuju" Kabupaten Blitar awalnya menamakan diri mereka dengan Koalisi Rakyat Blitar Berjuang. Kelompok ini melakukan deklarasi pada tanggal 13 Juni 2015 (lihat gambar 4). Koalisi Rakyat Blitar Berjuang

Gambar 4

Foto Deklarasi Kelompok Blitar Berjuang Kabupaten Blitar

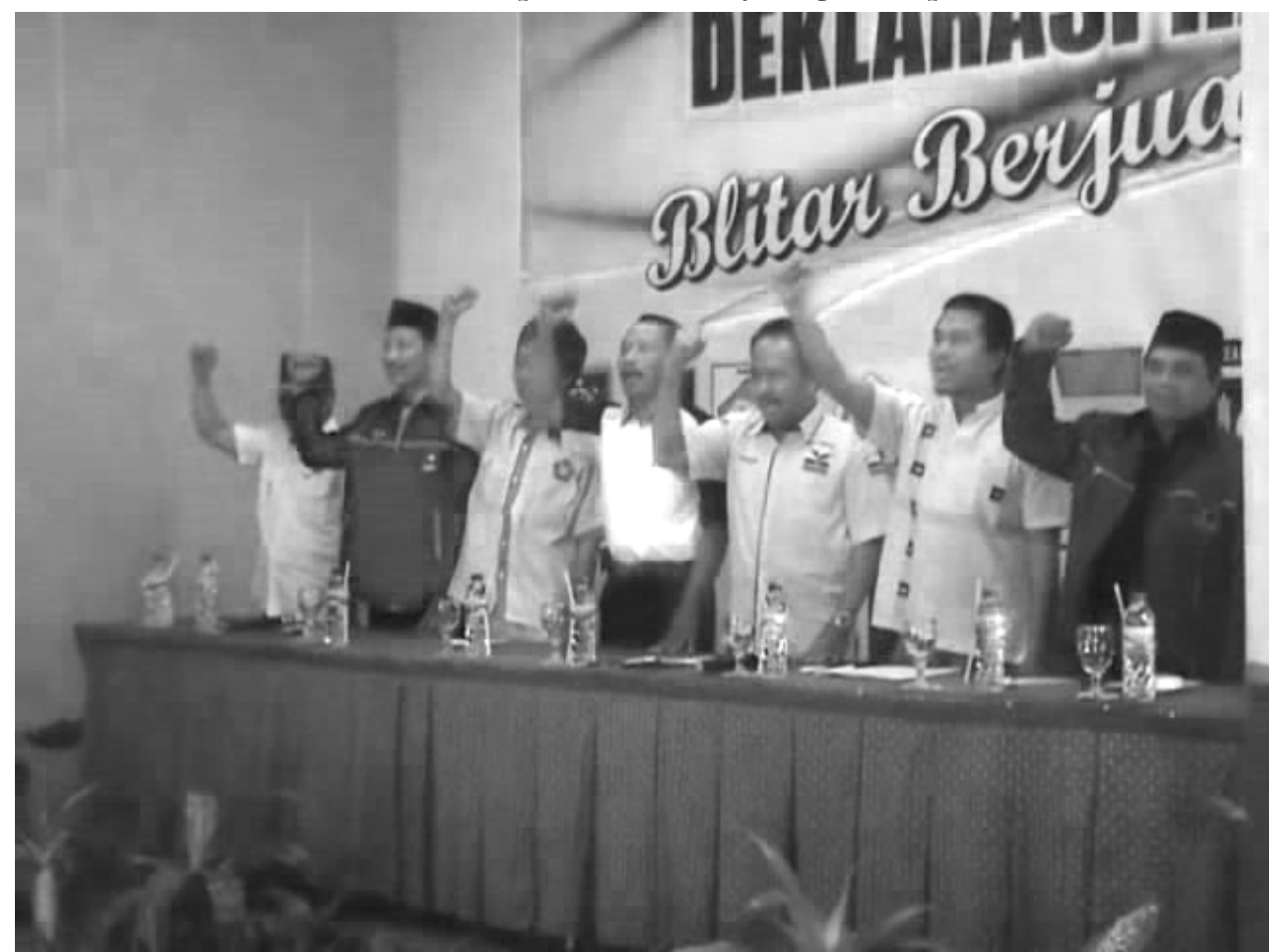

Sumber: pojokpitu.com

terbiasa untuk mencoblos pilihan gambar. terdiri dari sembilan partai politik yang memiliki Sementara, Pilkada calon tunggal menggunakan 34 kursi di DPRD Kabupaten Blitar. Sembilan

\footnotetext{
20 "Polemik Pilkada Calon Tunggal di Kabupaten Tasikmalaya", diakses 6 Desember 2015, pukul 14:20 WIB, http://www.bbc.com/indonesia/berita_indonesia/2015/12/ 151204_indonesia_pilkada_calontunggal.
}
21 "Polemik Pilkada Calon Tunggal di Kabupaten Tasikmalaya", diakses 6 Desember 2015, pukul 14:20 WIB, http://www.bbc.com/indonesia/berita_indonesia/2015/12/ 151204_indonesia_pilkada_calontunggal.


parpol koalisi tersebut di antaranya adalah PKB, PAN, Gerindra, Demokrat, PKS, PPP, Nasdem dan Hanura. Pada awalnya mereka akan mengusung kader terbaiknya guna memimpin Kabupaten Blitar dan mereka menginginkan adanya perubahan ke arah yang lebih baik. ${ }^{22}$

Koordinator Koalisi Suswati yang juga anggota DPRD dari Partai Golkar mengatakan, koalisi ini dibangun atas dasar kesamaan pandangan dan pemikiran. Dalam koalisi ini semua parpol memiliki hak yang sama dalam mengusung calon. Namun koalisi ini tetap akan membuka lebar-lebar terhadap siapapun putra daerah yang ingin maju sebagai calon bupati dan calon wakil bupati Blitar melalui partai koalisi. ${ }^{23}$

Dalam perkembangannya, Koalisi Rakyat Blitar Berjuang tidak berhasil menemui mufakat mengenai siapa yang akan dicalonkan di Pilkada Kabupaten Blitar 2015. Karena ketokohan dari Wakil Bupati Blitar petahana yang begitu kuat dan koalisi besar tidak berhasil juga menyepakati calon, koalisi ini memutuskan untuk tidak mengajukan calon agar Pilkada Kabupaten Blitar tahun 2015 ditunda menjadi tahun 2017. Bahkan, sebagai salah satu cara untuk membuat Wakil Bupati petahana tidak bisa memiliki waktu untuk mengajukan calon boneka (dalam wujud calon perseorangan), Koalisi Rakyat Blitar Berjuang mewacanakan di perpanjangan ketiga pendaftaran calon kepala daerah ke KPU bahwa mereka akan mendaftarkan Heri Romadlon (Wakil Ketua DPRD Blitar dari PAN) dan Nur Fathoni (pengusaha) sebagai bakal pasangan calon bupati dan wakil bupati Blitar. ${ }^{24}$

\footnotetext{
22 "9 Partai Deklarasi Koalisi Rakyat Blitar Berjuang", diakses 8 Agustus 2016 pukul 20:20 WIT, "http://www.pojokpitu. $\mathrm{com} /$ baca.php idurut $=8222 \& \&$ top $=1 \& \& \mathrm{ktg}=\mathrm{J} \% 20$ Mataraman\&\&keyrbk $=$ Pilkada $\& \&$ keyjdl $=$ koalisi $\% 20$ kabupaten\%20blitar.

23 "9 Partai Deklarasi Koalisi Rakyat Blitar Berjuang", diakses 8 Agustus 2016 pukul 20:20 WIT, 'http://www.pojokpitu. $\mathrm{com} /$ baca.php?idurut $=8222 \& \&$ top $=1 \& \& \mathrm{ktg}=\mathrm{J} \% 20$ Mataraman\&\&keyrbk=Pilkada\&\&keyjdl=koalisi\%20 kabupaten\%20blitar.

24 Wawancara dengan Mujib, anggota DPRD Kabupaten Blitar dari Partai Gerindra, tanggal 2 September 2016 di rumah Mujib, di Kabupaten Blitar.
}

Target dari Koalisi Rakyat Blitar Berjuang adalah Pilkada Kabupaten Blitar ditunda ke tahun 2017. Akan tetapi, ketika kemudian MK memutuskan Pilkada di Kabupaten Blitar tetap dilaksanakan pada tahun 2015, kelompok ini mengubah nama mereka menjadi "Forum Blitar Menggugat".

Forum Blitar Menggugat melakukan desakan kepada KPU Kabupaten Blitar untuk tidak melanjutkan penyelenggaraan Pilkada Serentak tahun 2015. Alasannya adalah karena ada kesan pelaksanaan itu dipaksakan tanpa mempertimbangkan situasi politik di daerah. Penyelenggaraan Pilkada yang disiapkan dengan waktu hanya dua bulan saja juga berpotensi menghasilkan persoalan baru. Di samping itu, massadariForum inimenyatakan penyelenggaraan Pilkada yang tidak didasari oleh Peraturan KPU khusus calon tunggal dianggap tidak sah. ${ }^{25}$

Berdasarkan pertimbangan-pertimbangan di atas, massa Forum Blitar Menggugat menolak Pilkada 2015 dan meminta kepada Panwas Kabupaten Blitar untuk membuat rekomendasi kepada KPU Kabupaten Blitar untuk menghentikan pelaksanaan Pilkada. Jika KPU dan Panwas tetap melaksanakan Pilkada di tahun 2015, maka mereka mengancam akan melaporkan kedua lembaga kepada DKPP. ${ }^{26}$

Akan tetapi, meskipun mendapatkan tekanan dari Forum Blitar Menggugat, KPU Kabupaten Blitar akhirnya tetap melaksanakan Pilkada Kabupaten Blitar pada 9 Desember 2015. KPU berpegangan pada prinsip bahwa mereka adalah eksekutor aturan. Pembuat aturan atau regulator adalah KPU RI.

Karena Pilkada calon tunggal tetap dilaksanakan, Forum Blitar Menggugat kemudian memutuskan untuk memperjuangkan agar pilihan "tidak setuju" bisa mengalahkan pilihan "setuju" sekaligus memperjuangkan

25 "Forum Blitar Menggugat Pilkada Kabupaten", diakses 8 Agustus 2016 pukul 20: 20 WIT, http://www.pojokpitu. $\mathrm{com} /$ baca.php idurut $=16653 \& \&$ top $=1 \& \& \mathrm{ktg}=\& \&$ key rbk $=$ Pilkada\&\&keyjdl = pilkada .

26 "Forum Blitar Menggugat Pilkada Kabupaten", diakses 8 Agustus 2016 pukul 20:20 WIT, http://www.pojokpitu. $\mathrm{com} /$ baca.php? idurut $=16653 \& \& \mathrm{top}=1 \& \& \mathrm{ktg}=\& \&$ key $\mathrm{rbk}=$ Pilkada\&\&keyjdl$=$ pilkada . 
perlakuan yang setara dengan pilihan "setuju". Meskipun tidak diakui seperti halnya calon, layaknya di Kabupaten Tasikmalaya, KPU RI tetap melaksanakan kegiatan persiapan Pilkada calon tunggal dalam bentuk simulasi. Simulasi itu digelar bukan untuk memberikan kesetaraan perlakuan terhadap pilihan "tidak setuju" melainkan untuk tujuan meminimalisir kesalahan masyarakat yang wilayahnya hanya memiliki satu pasangan calon saja. Simulasi itu dilakukan KPU RI di TPS 03 Desa Pagerwojo, Kecamatan Kesamben, Kabupaten Blitar, Jawa Timur, pada hari Minggu 21 November 2015. ${ }^{27}$

Menurut Komisioner KPU Hadar Nafis Gumay, simulasi ini dilakukan agar pemilih tahu tata cara memilih dengan benar, karena hanya diikuti satu pasangan calon. "Diharapkan simulasi ini dapat dipahami dan berjalan dengan baik. Jika ada kekurangan, itu akan disempurnakan kemudian," kata Hadar. Komisioner KPU ini menjelaskan, pemilih hanya perlu mencoblos salah satu pilihan, "setuju" atau "tidak setuju". "Jika dalam perhitungannya nanti banyak yang "setuju" maka, calon bisa menjadi kepala daerah. Begitu juga sebaliknya," ujarnya. ${ }^{28}$

Suara akan sah jika pemilih mencoblos satu antara dua pilihan tersebut. Tapi surat suara juga sah jika di coblos pada gambar dan kolom "setuju", atau gambar dan kolom "tidak setuju". "Namun suara tidak sah jika mencoblos pada gambar pasangan calon saja," katanya. ${ }^{29}$

\section{Kelompok “Tidak Setuju” di Pilkada Kabupaten Timor Tengah Utara}

Kelompok "tidak setuju" di Kabupaten Timor Tengah Utara seperti halnya yang terjadi

27 "KPU Gelar Simulasi Pilkada Calon Tunggal", diakses 8 Agustus 2016 pukul 20: 15 WIT, http://nasional.news. viva.co.id/news/read/702424-kpu-gelar-simulasi-pilkadacalon-tunggal-di-blitar.

28 "KPU Gelar Simulasi Pilkada Calon Tunggal", diakses 8 Agustus 2016 pukul 20: 15 WIT, http://nasional.news. viva.co.id/news/read/702424-kpu-gelar-simulasi-pilkadacalon-tunggal-di-blitar.

29 "KPU Gelar Simulasi Pilkada Calon Tunggal", diakses 8 Agustus 2016 pukul 20: 15 WIT, http://nasional.news. viva.co.id/news/read/702424-kpu-gelar-simulasi-pilkadacalon-tunggal-di-blitar. di Kabupaten Tasikmalaya, awalnya hanya terdiri dari para elite politik di Kabupaten Timor Tengah Utara. Namun, dalam perkembangannya, meluas sampai dengan kelompok mahasiswa di wilayah itu. Elite partai politik yang masuk dalam kelompok "tidak setuju" adalah para elite partai politik di luar dari PDI Perjuangan. Sementara itu, kelompok mahasiswa yang masuk dalam kelompok "tidak setuju" menamakan diri mereka dengan "Gebrak".

Pada awalnya, ada delapan partai politik (minus Partai Golkar) yang menamakan diri dengan Koalisi Era TTU Barru menyatakan ingin maju dalam Pilkada Kabupaten Timor Tengah Utara melawan Bupati Timor Tengah Utara petahana, Raymondous Sau Fernandes. Koalisi Era TTU Barru ini pun melakukan usaha persiapan yang tidak sekedarnya. Untuk meyakinkan diri, mereka melakukan survei internal yang dibiayai oleh mereka sendiri. Menurut pengakuan dari Hendro Meko:
"Jadi terus terang oke, waktu dari awal kita bangun koalisi ini kita sudah punya satu figur dalam hal ini calon bupati kami, satu. Anda bergabung koalisi dengan kami, cuma satu usung satu. Dan mereka siap. Jadi untuk mencari pendampingnya kita memakai survey. Saat itu kita pakai indosurvei dari Pak Muhammad Qodari. Memang survey saat itu..Terus terang hasilnya elektabilitas petahana memang di atas, ya to. Lumayan, jauh lah. Presentasinya juga saya kurang ingat, udah ini. Jadi gitu. Masuk lah Pak Eusebio masuk. Namun saya bilang semua ini kan tidak ada hal yang tidak mungkin, kita jangan pesimis dengan hasil survey itu ya kalau bisa kita kan kerja, kerja kan gitu. ${ }^{30}$

Di internal Koalisi Era TTU Barru terdapat dinamika antara tetap mengajukan calon atau tidak. Akan tetapi, akhirnya koalisi Era TTU Barru tidak berhasil mencapai mufakat untuk mengajukan Eusebio bersama calon wakil Bupati mereka, yaitu Raymondous Loin. Selain alasan hasil survei, mereka juga memiliki perhitungan sendiri sehingga menyebabkan mereka kemudian beralih kepada keputusan untuk

\footnotetext{
30 Wawancara dengan Hendro Meko, Pengurus Partai Nasdem Kabupaten Timor Tengah Utara, tanggal 8 Agustus 2016 di rumah Hendro Meko, di Timor Tengah Utara.
} 


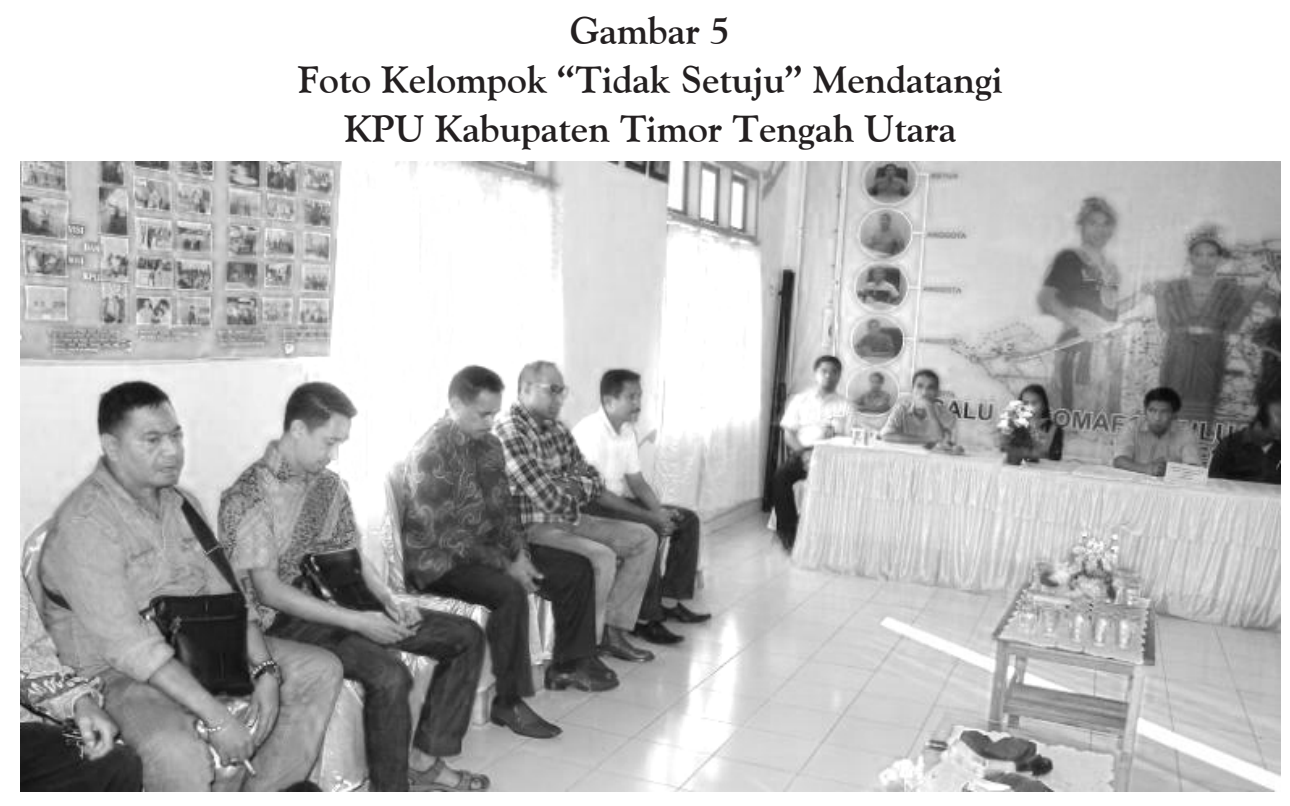

Sumber: mediantt.com

tidak mengajukan calon kepala daerah dalam Pilkada Kabupaten Timor Tengah Utara 2015. Tujuannya adalah agar Pilkada tahun 2015 ditunda ke tahun 2017 dan mereka memiliki persiapan lebih panjang lagi. Di samping itu, Bupati petahana saat Pilkada tahun 2017 bukan lagi menjabat sebagai bupati sehingga berstatus sama dengan calon yang akan mereka ajukan.

Karena sudah ditunda tiga kali tidak ada yang mendaftar, maka KPU Kabupaten Timor Tengah Utara memutuskan untuk menunda Pilkada Kabupaten Timor Tengah Utara menjadi dilaksanakan di tahun 2017. Akan tetapi, sebulan setelah itu, MK mengelurkan putusan yang mengamanatkan agar Pilkada di Kabupaten Timor Tengah Utara tetap dilaksanakan di tahun 2015.

Ditambahkan oleh Hendro Meko, dalam perkembangannya ada perubahan ketika MK mengeluarkan putusan di mana Pilkada di Kabupaten Timor Tengah Utara tetap dilaksanakan di tahun 2015. Koalisi Era TTU Barru tidak menyangka MK akan mengeluarkan putusan seperti itu. Menurut Hendro Meko:

"Kita tidak tahu bahwa ada uji matericalon tunggal di MK. kita tidak diarahkan kesitu. Makanya ketika pada tahap ketiga kita mendaftar, ternyata setelah uji materi incumbent menangkan calon tunggal, di situlah kita tidak bisa berbuat apa-apa. Positifnya ya kita tidak merasa kecewa." 31

\footnotetext{
31 Wawancara dengan Hendro Meko, Pengurus Partai Nasdem Kabupaten Timor Tengah Utara, tanggal 8 Agustus 2016 di rumah Hendro Meko, di Timor Tengah Utara.
}

Sebagai bentuk respons dari tetap dilaksanakannya Pilkada di tahun 2015, koalisi Era TTU Barru melakukan protes ke KPU Kabupaten Timor Tengah Utara. Mereka menilai bahwa tetap dilaksanakannya Pilkada di tahun 2015 adalah cacat hukum. Seperti diungkapkan oleh Miguel Atti Bau, Koordinator Koalisi Era TTU Barru:

"Di TTU itu yang ada itu pendaftar tunggal sebetulnya, bukan calon tunggal. Tetapi akhir dari semua itu kan ya kita sebagai negara hukum MK lahir seolah-olah 8 orang- 9 orang di Mahkamah Konstitusi itu yang menentukan. Karena TTU ini putusan Mahkamah Konstitusi jilid pertama Edi Meol menang, yang sekarang ini cacat hukum. Datang lagi putusan Mahkamah Konstitusi jilid dua mengakui calon tunggal. Ya ini lucu lah ya. Ibarat kalau orang bertarung, tinju itu tho tanpa lawan. Kita ibaratnya bertarung sendiri di atas ring dan lain sebagainya setelah itu dinyatakan menang. Nah ini yang sebetulnya diharapkan kalau bisa pemilu 2017, 2019 itu pemerintah dan DPR RI harus melihat kembali itu semua dengan baik." 32

Selain memprotes tetap dilaksanakannya Pilkada calon tunggal, koalisi Era TTU Barru melanjutkan kegiatan mereka dengan menyuarakan pilihan "tidak setuju" dan menuntut perlakuan yang setara dengan pilihan "setuju". Selain dilakukan oleh para elite politik dalam koalisi Era TTU Barru, protes terhadap

32 Wawancara dengan Miguel Atti Baru, tanggal 10 Agustus 2016 di rumah Miguel Atty Bau di Timor Tengah Utara. 
pelaksanaan Pilkada Timor Tengah Utara yang tidak memberikan perlakukan yang sama antara pilihan "setuju" dan "tidak setuju" juga dilakukan oleh kelompok mahasiswa yang menamakan diri mereka dengan "Gebrak". Seperti diungkapkan oleh Ernesto yang juga merupakan Sekretaris FMN Timor Tengah Utara:

"Kemarin pasca putusan MK, kita lebih banyak persoalkan terkait Peraturan KPU No. 14 Tahun 2015 itu terkait tidak terakomodirnya pemilih yang berada di kelompok yang tidak setuju. Di peraturan itu kan jelas bahwa yang memilih setuju `kan difasilitasi, disediakan body host, disediakan specimen surat suara, dengan paku yang jelas mengarah ke kolom setuju. Nah pertanyaan kita waktu itu bagaimana dengan kelompok masyarakat yang tidak setuju? terkait itu saja, kemudian awal-awal sebelumnya kita coba dekati beberapa partai politik untuk kita bangun diskusi kenapa mereka tidak punya kader untuk kemudian diusulkan ke KPU, didaftarkan ke KPU." 33

Ditambahkan oleh Ernezto, bahwa Pilkada Kabupaten Timor Tengah Utara juga cacat hukum. Pasalnya, ada kejanggalan dalam perlakuan KPU Timor Tengah Utara ketika pelaksanaan kampanye. Menurutnya:

"oh kalau yang cacat hukum itu kita temukan -saya lupa hadirkan contoh specimen surat- kita temukan satu specimen surat suara, itu dibagikan langsung oleh anggota TPS di desa Eban, di Desa Ulasi, itu dia bagikan satu specimen, itu specimen sosialisasi resmi ini. TPS ini kan dari KPU, nah saat sosialisasi dia bawa itu satu' contoh specimen surat suara kemudian ditunjukkan kepada masyarakat. Dalam specimen surat suara itu kita temukan terlihat jelas-jelas ada paku yang mengarah ke kolom 'setuju'. nah ini 'kan seolaholah ada pemaksaan bahwa Pilkada kali ini tidak boleh ada opsi lain selain pilih setuju. makanya kita anggap itu cacat hukum. Kemudian terkait dengan pengaktifan kembali BPS, Panwas dan lain-lainnya; kan sebelumnya itu kemudian dinonaktifkan setelah ditemukan hanya ada satu pasangan calon yang mendaftar itu kemudian oleh KPU di nonaktifkan melalui SK yang resmi. Pasca putusan MK, KPU tanpa melalui suatu mekanisme yang resmi, yang jelas secara lisan

33 Wawancara dengan Ernezto, tanggal 13 Agustus 2016 di rumah Ernezto, di Timor Tengah Utara. bahkan waktu itu, disampaikan bahwa seluruh perangkat yang ada itu di aktifkan begitu saja. Padahal mestinya kan harus ada melalui tahapan seleksi kan sebagai pembukaan pendaftaran itu juga dibuka secara terbuka. Mestinya begitu. ${ }^{34}$

\section{Perbandingan Ketiga Kasus Pilkada Calon Tunggal Tahun 2015}

Bagaimana perbandingan antara ketiga kasus Pilkada calon tunggal Tahun 2015? Hal itu bisa dilihat dari persamaan dan perbedaan di antara ketiganya.

Ada setidaknya dua persamaan di antara ketiga kasus. Persamaan pertama adalah di ketiga daerah kelompok "tidak setuju" diperlakukan tidak setara dengan kelompok "setuju" yang notabene adalah calon dan merupakan kepala daerah atau wakil kepala daerah incumbent. Persamaan kedua ialah tujuan awal dari kelompok "tidak setuju" adalah ingin

\section{Tabel 1}

Persamaan Ketiga Kasus Pilkada Calon Tunggal Tahun 2015

\begin{tabular}{|c|c|c|}
\hline $\begin{array}{c}\text { Kabupaten/ } \\
\text { Indikator }\end{array}$ & $\begin{array}{c}\text { Perlakuan } \\
\text { Terhadap } \\
\text { Kelompok } \\
\text { "Tidak Setuju" }\end{array}$ & $\begin{array}{l}\text { Tujuan Awal } \\
\text { Kelompok } \\
\text { "Tidak Setuju" }\end{array}$ \\
\hline Tasikmalaya & $\begin{array}{l}\text { Tidak diakui } \\
\text { secara setara } \\
\text { dengan kelompok } \\
\text { "setuju" yang } \\
\text { notabena adalah } \\
\text { calon incumbent }\end{array}$ & $\begin{array}{l}\text { Ingin mengundur } \\
\text { Pilkada Serentak } \\
2015 \text { agar } \\
\text { dilaksanakan di } \\
\text { Tahun } 2017\end{array}$ \\
\hline Blitar & $\begin{array}{l}\text { Tidak diakui } \\
\text { secara setara } \\
\text { dengan kelompok } \\
\text { "setuju" yang } \\
\text { notabena adalah } \\
\text { calon incumbent }\end{array}$ & $\begin{array}{l}\text { Ingin mengundur } \\
\text { Pilkada Serentak } \\
2015 \text { agar } \\
\text { dilaksanakan di } \\
\text { Tahun } 2017\end{array}$ \\
\hline $\begin{array}{l}\text { Timor } \\
\text { Tengah } \\
\text { Utara }\end{array}$ & $\begin{array}{l}\text { Tidak diakui } \\
\text { secara setara } \\
\text { dengan kelompok } \\
\text { "setuju" yang } \\
\text { notabena adalah } \\
\text { calon incumbent }\end{array}$ & $\begin{array}{l}\text { Ingin mengundur } \\
\text { Pilkada Serentak } \\
2015 \text { agar } \\
\text { dilaksanakan di } \\
\text { Tahun } 2017\end{array}$ \\
\hline
\end{tabular}

Sumber: Diolah penulis.

34 Wawancara dengan Ernezto, tanggal 13 Agustus 2016 di rumah Ernezto, di Timor Tengah Utara. 
membuat waktu pelaksanaan Pilkada Serentak 2015 diundur ke Pilkada Serentak tahun 2017. Dalam perkembangannya, ketiganya melanjutkan kegiatannya dengan bertujuan untuk mengkampanyekan pilihan "tidak setuju" sembari meminta diberikannya perlakuan yang setara dengan kelompok "setuju”.

Sementara itu, untuk perbedaan juga paling tidak ada dua perbedaan di antara ketiga kasus. Perbedaan pertama adalah penyebab terjadinya Pilkada calon tunggal. Dalam kasus Pilkada Kabupaten Tasikmalaya, penyebab terjadinya Pilkada calon tunggal adalah kesepakatan elite politik untuk sama-sama tidak mencalonkan diri agar Pilkada diundur menjadi dilaksanakan tahun 2017. Meskipun demikian, akhirnya MK mengeluarkan putusan yang menggagalkan rencana mereka. Sementara itu, dalam kasus Pilkada Kabupaten Blitar, penyebab terjadinya Pilkada calon tunggal adalah tidak adanya calon yang ingin maju dalam Pilkada kecuali wakil bupati petahana. Kondisi hanya satu calon itu kemudian diperkuat oleh putusan MK. Sedangkan, untuk kasus Pilkada Kabupaten Timor Tengah Utara, penyebab Pilkada calon tunggal adalah bakal calon kepala daerah lawan petahana tidak jadi mencalonkan agar Pilkada diundur ke tahun 2017. Namun kemudian, rencana mereka itu digagalkan oleh putusan MK.

Perbedaan kedua adalah bentuk protes kelompok "tidak setuju". Di Kabupaten Tasikmalaya, bentuk protes terdiri dari demonstrasi terhadap KPUD, demonstrasi di depan kantor Bupati, dan pemasangan spanduk dan alat peraga yang mengkampanyekan tidak setuju. Di Kabupaten Blitar, bentuk protes kelompok "tidak setuju" di daerah itu dilakukan dengan protes kepada Panwas dan protes kepada KPUD setempat. Sementara itu di Kabupaten Timor Tengah Utara, bentuk protes kelompok "tidak setuju” dilakukan dengan cara protes kepada Panwas dan demonstrasi ke kantor KPUD setempat.

\section{Tabel 2}

Perbedaan Ketiga Kasus Pilkada Calon Tunggal Tahun 2015

\begin{tabular}{|c|c|c|}
\hline $\begin{array}{c}\text { Kabupaten/ } \\
\text { Indikator }\end{array}$ & $\begin{array}{c}\text { Penyebab } \\
\text { Terjadinya } \\
\text { Pilkada } \\
\text { Calon } \\
\text { Tunggal }\end{array}$ & $\begin{array}{l}\text { Bentuk Protes } \\
\text { Kelompok "TIdak } \\
\text { Setuju" }\end{array}$ \\
\hline Tasikmalaya & $\begin{array}{l}\text { Kesepakatan } \\
\text { sama- } \\
\text { sama tidak } \\
\text { mencalonkan } \\
\text { yang } \\
\text { kemudian } \\
\text { rencana } \\
\text { mengundur } \\
\text { Pilkada } \\
\text { digagalkan } \\
\text { oleh putusan } \\
\text { MK }\end{array}$ & $\begin{array}{l}\text { - Demonstrasi } \\
\text { terhadap KPUD } \\
\text { - Demonstrasi di } \\
\text { depan kantor } \\
\text { Bupati } \\
\text { - Memasang } \\
\text { spanduk dan } \\
\text { alat peraga yang } \\
\text { mengkampanyekan } \\
\text { tidak setuju }\end{array}$ \\
\hline Blitar & $\begin{array}{l}\text { Tidak ada } \\
\text { calon yang } \\
\text { ingin maju } \\
\text { dalam } \\
\text { Pilkada } \\
\text { kecuali } \\
\text { wakil bupati } \\
\text { petahana } \\
\text { yang } \\
\text { kemudian } \\
\text { diperkuat } \\
\text { putusan MK }\end{array}$ & $\begin{array}{l}\text { - Protes kepada } \\
\text { Panwas } \\
\text { - Protes kepada } \\
\text { KPUD }\end{array}$ \\
\hline $\begin{array}{l}\text { Timor } \\
\text { Tengah } \\
\text { Utara }\end{array}$ & $\begin{array}{l}\text { Bakal calon } \\
\text { kepala } \\
\text { daerah lawan } \\
\text { petahana } \\
\text { tidak jadi } \\
\text { mencalonkan } \\
\text { dan } \\
\text { kemudian } \\
\text { digagalkan } \\
\text { oleh putusan } \\
\text { MK }\end{array}$ & $\begin{array}{l}\text { - Protes kepada } \\
\text { Panwas } \\
\text { - Demonstrasi ke } \\
\text { kantor KPUD }\end{array}$ \\
\hline
\end{tabular}

Sumber: Diolah penulis.

\section{Penyebab Tidak Diakomodirnya Kelompok "Tidak Setuju" di Tiga Pilkada Calon} Tunggal Tahun 2015

Adanya kelompok "tidak setuju” yang tidak diakomodir di tiga daerah seperti diuraikan di atas kemudian menimbulkan pertanyaan yang 
menarik untuk dijawab dan didiskusikan. Khususnya, yang menjadi pertanyaan adalah faktor apa yang menjadi penyebab hal itu terjadi.

Ketua KPU Kabupaten Tasikmalaya misalnya mengungkapkan bahwa berbeda dengan Pilkada daerah lain yang terdiri dari minimal dua pasang calon, Pilkada calon tunggal termasuk yang terjadi di daerahnya memiliki beberapa ciri khas. Diungkapkan oleh Ketua KPU Kabupaten Tasikmalaya:

"Pasti ada banyak hal yang berubah. Ada empat hal yang berubah. Pertama tadi karena calon tunggal. Orang kalau masyarakat itu kan, dulu kalau nyoblos pasangan calon pasti sah. Pokoknya. Sekarang tidak sah malah. Orang harus nyoblosnya setuju atau tidak setuju. Kedua, perbedaan dari sisi kampanye. Kampanye pun kan, orang bagaimana akan mengkampanyekan tidak setuju. Ternyata di KPU 2014 tidak diatur. Ini paling tidak tantangan tersendiri juga. Yang ketiga dalam hal masalah penyampaian sosialisasi ke masyarakat. Tidak semudah membalikkan telapak tangan. Yang keempat tentang persoalan masalah aturan kampanye yang baru ini, yang serentak ini. Segala macam diberi KPU. Segala macam APK, bahan sosialisasi. Sehingga dipandang seolah-olah ada yang menyesal dari pasangan yang tadi gak daftar. Ini menarik. Ini ada kayak penyesalan. Buktinya kesana. Kok enak banget calon, nah kenapa ada bilang gak nyalon kemaren. ${ }^{35}$

Di Kabupaten Timor Tengah Utara, concern terhadap tidak diakomodirnya kelompok "tidak setuju" dalam Pilkada calon tunggal tahun 2015 datang dari Sekjen FMN Timor Tengah Utara, Ernezto. Seperti diungkapkan oleh Ernezto:

"Kemarin pasca putusan MK, kita lebih banyak persoalkan terkait Peraturan KPU No. 14 Tahun 2015 itu terkait tidak terakomodirnya pemilih yang berada di kelompok yang tidak setuju. Di peraturan itu kan jelas bahwa yang memilih setuju `kan difasilitasi, disediakan body host, disediakan specimen surat suara, dengan paku yang jelas mengarah ke kolom setuju. Nah pertanyaan kita waktu itu bagaimana dengan kelompok masyarakat yang tidak setuju? Kalau

35 Wawancara dengan Deden, Ketua KPU Kabupaten Tasikmalaya di Kantor KPU Kabupaten Tasikmalaya, pada tanggal 21 November 2015. itu yang kaitannya sama surat suara itu dia ada di dalam gambarnya, atau atau pada saat simulasinya di arahkannya ke 'setuju' oleh TPS atau.itu ada dalam gambarnya di specimen surat suara itu tapi yang nggak setuju nggak di.. tidak ada pakunya. Hanya satu jenis. Kita bahkan sempat tanya pada orang yang bersangkutan melalui TPS yang sebarkan itu dia hanya bilang ini jalankan perintah KPU. Nah kemudian kita persoalkan terkait paku katanya ini rekomendasi oleh undang-undang diperbolehkan katanya. Oleh peraturan itu diperbolehkan diserahkan kepada partai politik yang mengusung calon tunggal untuk mendesain. Kemudian diberikan pada KPU untuk KPU fasilitasi pembuatannya. Jadi waktu itu alasannya disitu." 36

Lantas, apa penyebab dari tidak diakomodirnya kelompok "tidak setuju" dalam Pilkada calon tunggal tahun 2015? Jawabannya adalah karena ketiadaan aturan yang dapat mengakomodir persoalan-persoalan yang muncul terkait Pilkada calon tunggal. Tidak seperti Pilkada calon tunggal tahun 2017 yang mana aturannya ada di UU No. 10 Tahun 2016, Pilkada calon tunggal tahun 2015 terjadi pasca keluarnya Putusan MK. Setelah keluarnya Putusan MK, tanpa melalui revisi Undang-Undang No. 8 Tahun 2015 lagi, KPU RI langsung bergerak melaksanakan perintah Putusan MK tersebut. Dengan demikian, maka ketentuan hukum Pilkada calon tunggal 2015 terdapat di Peraturan KPU, bukan UU.

Peraturan KPU khusus untuk Pilkada calon tunggal 2015 ada pada Peraturan KPU Nomor 14 Tahun 2015 tentang Pemilihan Gubernur dan Wakil Gubernur, Bupati dan Wakil Bupati, dan/atau Walikota dan Wakil Walikota dengan Satu Pasangan Calon. Jika ditelaah secara mendalam, maka dapat disimpulkan bahwa memang PKPU No. 14 Tahun 2015 sama sekali tidak mengakomodir kelompok "tidak setuju”. Di Bagian tentang Kampanye (Pasal 9 sampai dengan 13), terlihat bahwa PKPU hanya mengakui calon atau dengan kata lain kelompok "setuju" saja. Seperti di Pasal 9 ayat (1) disebutkan bahwa kampanye dalam Pilkada dengan satu pasangan calon dilaksanakan

\footnotetext{
36 Wawancara dengan Ernezto, tanggal 13 Agustus 2016 di rumah Ernezto di Timor Tengah Utara.
} 
oleh KPU dan pasangan calon dana atau tim kampanye. Pasal 9 ayat (4) juga menyebutkan bahwa pendanaan kampanye (terutama debat publik, penyebaran bahan kampanye kepada umum, pemasangan alat peraga kampanye, dan atau iklan di media massa cetak dan atau media elektronik) difasilitasi oleh Anggaran Pendapatan dan Belanja Daerah (APBD). Dari bagian kampanye dapat dilihat bahwa kelompok "setuju" alias pasangan calon diberi keuntungan besar karena diberi ruang untuk kampanye sekaligus didanai ketika melaksanakan kampanye.

Hal yang kurang lebih sama terjadi dalam hal debat publik. Debat publik didefinisikan penyampaian visi misi oleh pasangan calon. Sementara, kelompok "tidak setuju" tidak diberi ruang sama sekali seperti pasangan calon untuk menyampaikan materi debat publik mereka. Bahkan, lebih spesifik lagi, debat publik tidak sama sekali mengakui atau memberi kesempatan kepada kelompok "tidak setuju".

Dalam hal desain surat suara, di Pasal 14 PKPU No. 14 Tahun 2015 diatur bahwa foto pasangan calon berada di atas dari kolom "setuju" dan "tidak setuju". Desain seperti ini bermasalah karena tidak semua masyarakat paham dengan desain seperti ini. Apalagi masyarakat di ketiga kabupaten dengan Pilkada calon tunggal disebutkan tidak terbiasa dengan pilihan kolom tulisan. Masyarakat di ketiga daerah itu lebih terbiasa dengan pilihan gambar pasangan calon. Padahal, mencoblos gambar pasangan calon saja dinilai tidak sah.

Ketiadaan aturan yang menyebabkan tidak diakomodirnya kelompok "tidak setuju" dalam Pilkada calon tunggal tahun 2015 di ketiga daerah sejalan dengan apa yang disebut oleh Lijphart sebagai konsekuensi politik dari electoral laws atau regulasi atau aturan tentang pemilu. Disadari atau tidak oleh KPU RI sebagai pembuat PKPU No. 14 Tahun 2015, pengakomodiran kelompok "setuju" atau pasangan calon saja dengan tidak mengakui dan atau mengakomodir kelompok "tidak setuju" dalam model pemilihan referendum sama dengan mendiskriminasi apa yang menjadi pilihan masyarakat. Seperti diuraikan di atas, pasangan calon diberi kesempatan kampanye dan diberi "keistimewaan" di surat suara. Bahkan, menurut salah seorang informan di salah satu kabupaten, specimen surat suara yang dibuat oleh KPU terkesan mengarahkan kepada masyarakat atau pemilih untuk memilih pasangan calon atau pilihan "setuju" karena tidak ada model surat suara lain selain model specimen yang terdapat gambar paku di pilihan "setuju".

Penulis berpendapat sama dengan Lijphart bahwa peraturan pemilu memiliki pengaruh atau konsekuensi politik. Hanya saja, berbeda dengan apa yang dimaksud Lijphart dengan peraturan pemilu di dalam karyanya (yaitu sistem pemilu dan variabel-variabelnya), temuan penelitian ini memfokuskan pada peraturan pemilu menyangkut Pilkada calon tunggal. Meskipun demikian, hasil dan temuan penelitian ini menegaskan argumen Lijphart juga terbukti dalam kasus di tiga daerah dengan Pilkada calon tunggal tahun 2015, khususnya yang terkait dengan tidak adanya klausul yang mengakomodir kelompok "tidak setuju".

Bagaimana hubungan antara Pilkada calon tunggal tahun 2015 dan demokrasi? Dalam praktik Pilkada calon tunggal di tahun 2015, praktik perlakuan tidak setara terhadap kelompok "tidak setuju" tidak dapat dibenarkan dalam kacamata pemilu yang demokratis. Seperti yang dikatakan oleh Wayne bahwa pemilu yang demokratis harus terbebas dari adanya diskriminasi, maka pelaksanaan Pilkada calon tunggal tahun 2015 yang memberikan perlakuan tak sama antara untuk kelompok "setuju" dan "tidak setuju" yang diakibatkan aturan telah menyebabkan Pilkada calon tunggal gagal untuk menjadi Pilkada yang demokratis. Di samping itu, prinsip kesetaraan politik yang seharusnya ada dalam konteks perlakuan terhadap kelompok "setuju" dan kelompok "tidak setuju" namun ternyata tidak terjadi semakin menguatkan kesimpulan bahwa Pilkada calon tunggal makin tercederai untuk disebut sebagai Pilkada yang demokratis. 


\section{Simpulan}

Artikel ini membahas mengenai perlakuan tidak setara terhadap kelompok "tidak setuju" dalam Pilkada calon tunggal tahun 2015 di Kabupaten Tasikmalaya, Kabupaten Blitar, dan Kabupaten Timor Tengah Utara. Kelompok "tidak setuju" di ketiga daerah tersebut di atas tidak mendapat ruang untuk melakukan hal yang sama dan setara seperti halnya calon kepala daerah, bahkan terkesan tidak diakui. Penyebab perlakuan tidak setara terhadap kelompok "tidak setuju" adalah karena ketiadaan aturan yang dapat mengakomodir persoalan-persoalan yang muncul terkait Pilkada calon tunggal.

Selain itu, pelaksanaan Pilkada calon tunggal tahun 2015 di ketiga daerah yang memberikan perlakuan tidak setara kepada kelompok "tidak setuju" menyebabkan Pilkada di ketiga daerah tidak dapat disebut sebagai Pilkada yang demokratis. Pasalnya, ketiga Pilkada telah mempraktikkan diskriminasi dan tidak menjalankan prinsip kesetaraan politik.

\section{Rekomendasi}

Permasalahan tidak diakomodirnya kelompok "tidak setuju" dalam Pilkada calon tunggal tahun 2015 menjadi pelajaran untuk dilakukannya perbaikan ke depan sehingga permasalahan tersebut tidak terjadi kembali. Rekomendasi pertama dan utama adalah karena Pilkada calon tunggal lebih bermodelkan referendum daripada pemilu pada umumnya, maka tidak ada alasan bagi pembuat aturan sekaligus penyelenggara Pilkada tidak mengakomodir kelompok "tidak setuju". Pasalnya, kelompok "tidak setuju" diwakili oleh orang-orang yang mana orang-orang tersebut seharusnya mendapatkan perlakukan yang sama dan tidak dibedakan. Rekomendasi kedua adalah membuat aturan yang mengatur tentang diwajibkannya pengakuan akan pilihan "setuju" atau "tidak setuju". Ketiadaan pengaturan hal itu dilakukan agar tidak membuat penyelenggara di tiap daerah takut salah. Rekomendasi ketiga adalah bahwa Peraturan KPU No. 14 Tahun 2015 yang masih bernafaskan model pemilihan umum harus diubah sehingga menjadi bernafaskan model referendum. Tak terkecuali, PKPU No. 14 Tahun 2015 harus mengatur tentang bahan kampanye dan alat peraga kampanye yang juga dibiayai oleh negara sehingga tidak hanya untuk pasangan calon alias pilihan "setuju" saja.

Ke depan, penelitian tentang Pilkada calon tunggal sebagai sebuah fenomena baru penting untuk dilakukan. Terutama sekali, jika terdapat penelitian yang dapat menjawab dan menganalisis kepentingan politik di balik tidak diakomodirnya kelompok "tidak setuju" dalam Pilkada calon tunggal tahun 2015.

\section{DAFTAR PUSTAKA}

\section{Buku, Jurnal, dan Artikel Opini}

Benoit, Kenneth. "Duverger's Law and the Study of Electoral System", French Politics 4, (2006): 69-83. . "Electoral Laws as Political Consequences: Explaining the Origins and Change of Electoral Institutions", Annu. Rev. Polit. Sci. 10, (2007): 363-90.

Blais, Andre, Louis Massicotte, dan Antoine Yoshinaka. "Deciding Who Has The Right to Vote: A Comparative Analysis of Election Laws", Electoral Studies 20, no. 1 (March 2001): 41-62.

Bowler, Shaun, Elisabeth Carter, dan David M. Farrell. Studying Electoral Institutions and Their Consequences: Electoral Systems and Electoral Laws, ...................... CSD Working Papers, 2001. Diakses 21 Februari 2017, http://escholarship.org/uc/ item/7dc5b9dg.

Capoccia, Giovanni. "The Political Consequences of Electoral Laws: The German System at Fifty", West European Politics 25, no. 3 (2002): 171-202. 
Clark, William R. dan Matt Golder. "Rehabilitating Duverger's Theory: Testing the Mechanical and Strategic Modifying Effects of Electoral Laws", Comparative Political Studies 39, no. 6 (2006): 679-708.

Dhesinta, Wafia Silvi. "Calon Tunggal dalam Pemilihan Umum Kepala Daerah dan Konsep Demokrasi: Analisis Terhadap Pemilihan Kepala Daerah Kabupaten Blitar Tahun 2015", Jurnal Cita Hukum 4, no. 1 (2016), 87-104.

Darmawan, Ikhsan, "Mengantisipasi Pilkada Calon Tunggal.", Kompas, 14 September 2016.

Grofman, Bernard dan Arend Lijphart (Eds.), Electoral Laws and Their Political Consequences, Agathon Press Inc. New York, 1986.

Jones, Mark P. "The Political Consequences of Electoral Laws in Latin America and the Caribbean", Electoral Studies 12, no. 1 (1993), 59-75.

Kennedy, John James. "The Face of "Grassroots Democracy" in Rural China: Real Versus Cosmetic Elections", Asian Survey 42, no.3 (2002): 456-482.

Li, Cheng. From Selection to Election? Experiments in the Recruitment of Chinese Political Elities, China Leadership Monitor, No. 26.

Lijphart, Arend. "The Political Consequences of Electoral Laws, 1945-85", The American Political Science Review 84, no. 2 (June 1990): 481-496.

McDonald, Michael P. dan John Samples (Eds.). The Marketplace of Democracy: Normative and Empirical Issues. Washington DC: Brookings Institution Press, 2007.

O'Brien, Kevin J. dan Rongbin Han. "Path to Democracy?: Assesing Village Elections in China", Journal of Contemporary China 18, no. 60 (2009): 359-378.

Rae, Douglas. The Political Consequences of Electoral Laws. Yale: Yale University Press, 1967.
Still, Jonathan W. "Political Equality and Election Systems", Ethics 91, no. 3 (Apr., 1981): 375-394.

Wayne, Stephen J. Is This Any Way To Run a Democratic Election? Los Angeles: Sage Publication, 2014.

\section{Hasil Wawancara}

Wawancara dengan Deden, Ketua KPU Kabupaten Tasikmalaya pada tanggal 21 November 2015 di Kantor KPU Kabupaten Tasikmalaya.

Wawancara dengan Ernezto, Koordinator Gebrak Timor Tengah Utara pada tanggal 13 Agustus 2016 di rumah Ernezto, di Timor Tengah Utara.

Wawancara dengan Erry Purwanto, pengurus Partai Golkar Kabupaten Tasikmalaya di Gedung DPRD Kabupaten Tasikmalaya pada tanggal 6 Januari 2016.

Wawancara dengan Hendro Meko, Pengurus Partai Nasdem Kabupaten Timor Tengah Utara tanggal 8 Agustus 2016 di rumah Hendro Meko, di Timor Tengah Utara.

Wawancara dengan Ikbal Nasihin, salah satu pengurus PPP (Kubu Djan Faridz) di Kantor PPP (Kubu Djan Faridz) Kabupaten Tasikmalaya, pada tanggal 6 Januari 2016.

Wawancara dengan Mujib, anggota DPRD Kabupaten Blitar dari Partai Gerindra di Rumah Mujib, pada tanggal 2 September 2016.

Wawancara dengan Miguel Atti Baru, Koordinator Koalisi Era TTU Barru, pada tanggal 10 Agustus 2016 di rumah Miguel Atty Baudi Timor Tengah Utara.

Wawancara dengan Usman Kusmana, anggota DPRD Kabupaten Tasikmalaya di di Gedung DPRD Kabupaten Tasikmalaya pada tanggal 6 Januari 2016. 


\section{Sumber Internet}

"9 Partai Deklarasi Koalisi Rakyat Blitar Berjuang”, diakses 8 Agustus 2016 pukul 20:20 WIT, http://www.pojokpitu.com/ baca.php? idurut $=8222 \& \&$ top $=1 \& \&$ $\mathrm{ktg}=\mathrm{J} \% 20 \mathrm{Mataraman} \& \&$ keyrbk $=$ Pilka da \&\&keyjdl=koalisi\%20kabupaten $\% 20$ blitar.

"Forum Blitar Menggugat Pilkada Kabupaten", diakses 8 Agustus 2016 pukul 20:20 WIT, http://www.pojokpitu.com/baca.php?idurut $=16653 \& \&$ top $=1 \& \& \mathrm{ktg}=\& \&$ keyrbk $=\mathrm{P}$ ilkada\& $\&$ keyjdl $=$ pilkada.

"KPU Gelar Simulasi Pilkada Calon Tunggal", diakses 8 Agustus 2016 pukul 20:15 WIT, http://nasional.news.viva.co.id/news/ $\mathrm{read} / 702424-\mathrm{kpu}$-gelar-simulasi-pilkadacalon-tunggal-di-blitar.

"Mantan Bupati Kampanyekan Suara Tidak Setuju", diakses 8 November 2015, pukul 10:25 WIB, http://v2.rri.co.id/post/ berita/214082/pilkada_serentak_2015/ mantan_bupati_kampanyekan_suara_ tidak_setuju_di_tasikmalaya.html.
"Pasca putusan MA, PPP tak akan usung UU di Pilkada Tasikmalaya", diakses 8 November 2015, pukul 10:23 WIB, http://m. galamedianews.com/daerah/49796/pascaputusan-ma-ppp-tak-usung-uu-di-pilkadatasikmalaya.html.

"Polemik Pilkada Calon Tunggal di Kabupaten Tasikmalaya", diakses 6 Desember 2015, pukul 14:20 WIB, http://www.bbc.com/indonesia/berita indonesia/2015/12/151204_indonesia_ pilkada_calontunggal.

"Yemen holds presidential election with one candidate", http://edition.cnn. com/2012/02/21/world/meast/yemenelections/ (cnn.com). 